\title{
The influence of depth of plowing on the development and yield of winter wheat on chernozem soil
}

\author{
P. DREZGIC and S. JEVTIC
}

\section{Summary ${ }^{1}$}

During the 4-year period of investigation on the influence of depth and method of plowing on development and yield of winter wheat the following could be conluded:

Deep plowing to 35 and $45 \mathrm{~cm}$ according to the method of soil amelioration with the proper distribution of the mineral fertilizers favored a more regular water supply to the plants because of increased moisture storage in the soil. The greater quantity of water supply during the growing period, in addition to other improved conditions in the soil with deeper plowing enabled the following :

Stronger development of the root systeem during the whole vegetation period, a more regular distribution of the roots over various layers including the plow layer, and a more regular ratio of roots to overground parts. Furthermore, a higher total and active absorbing surface of the root system and stronger and deeper penetration of the roots enabled a better supply of water and nutritive elements to the plant. As a result, the overground parts were better developed, including overground mass and higher photosynthetic surface (leaf-surface).

With a more regular ratio of roots to overground parts and with a better and more regular water supply to the plant during the vegetation period the improved elements of yield were as follows : greater number of ears per sq. m., greater number of spikelets and grain per ear, better grain development (greater weight of the individual grain) wich finally resulted in higher yields per hectare.

Thus for the development of the root system and the wheat plant as a whole on the chernozem soil under the agroecological conditions of the Vojvodina, deep plowing of 35 and $45 \mathrm{~cm}$ according to the method of soil amelioration is considered to be best. Only in moist years plowing at once to the full depth, shallower plowing and plowing with subsoiling, gave better results. The advantage of deep plowing is especially pronounced in dry years wich are frequent in this region. Only in the extreme moist year $1958 / 59$ the value of deep tillage was not apparent.

1 Complete mimeographed text available on request from Tillage Laboratory State Agric. Univ., Diedenweg 20, Wageningen. 